\title{
Pesan Moral Dalam Tayangan Adzan Maghrib Di RCTI
}

\author{
Afner Gus Chandra \\ UIN Sunan Kalijaga Yogyakarta \\ Email: afnerguschandra94@gmail.com
}

\begin{abstract}
In this study raised the "Moral Message in Maghrib Adhan Impressions on RCTI" in the 2014/2015 period with the theme "Repentance". This researcher discusses how the moral message contained in the scene and storyline in the Magbrib prayer call on RCTI. This study uses a descriptive qualitative approach with the analysis used is semiotics according to Roland Barthes. Analysis of these impressions is based on the results of interviews with the Creative Team and documentation which are reviewed from the elements of the main cast and the storyline as a reference for data processing. As an indicator in this study is related moral character, including tawadhu', gentle, pious charity, compassion, patience, and forgiveness. From the research it was known that in the adzan show with the theme "Bertaubat", it featured several scenes containing positive moral messages. The moral message is the nature of tawadhu 'wbich is carried out when meeting other people and older people, gentle nature in association, good deeds in living life, full affection for a mother, patience in living relationships and life among fellow bumans, and always give forgiveness to others, even though that person has done evil. The final message at the adzan show is forgiveness among others in an effort to gain victory and unity.
\end{abstract}

Keywords: Adhan, Impressions, Moral Message, Visual.

\begin{abstract}
Abstrak
Dalam penelitian ini mengangkat tentang "Pesan Moral dalam Tayangan Adzan Maghrib di RCTI" pada periode 2014/2015 dengan tema "Bertaubat". Peneliti ini membahas tentang bagaimana pesan moral yang tekandung dalam adegan dan storyline dalam tayangan adzan maghrib di RCTI. Penelitian ini menggunakan pendekatan kualitatif deskriptif dengan analisis yang digunakan adalah semiotika menurut Roland Barthes. Analisis terhadap tayangan ini berdasarkan hasil wawancara kepada Tim Kreatif dan dokumentasi yang ditinjau dari unsur adegan-adegan pada pemeran utama dan storyline sebagai acuan pengolah data. Sebagai indikator dalam penelitian ini adalah terkait moral akhlak, diantaranya tawadhu', lemah lembut, beramal shaleh, kasih sayang, sabar, dan pemaaf. Dari penelitian diketahui bahwa dalam tayangan adzan dengan tema "Bertaubat", menampilkan beberapa adegan yang mengandung pesan moral positif. Pesan moral tersebut yaitu sifat tawadhu' yang dilakukan
\end{abstract}


saat bertemu orang lain dan orang yang lebih tua, sifat lemah lembut dalam pergaulan, beramal shaleh dalam menjalani kehidupan, kasih sayang yang penuh kepada seorang ibu, sabar dalam menjalani pergaulan dan kehidupan antar sesama manusia, serta senantiasa memberikan maaf kepada orang lain, meskipun orang tersebut telah berbuat jahat. Pesan akhir pada tayangan adzan tersebut adalah memaafkan antar sesama sebagai upaya untuk mendapatkan kemenangan dan persatuan.

Kata Kunci: Adzan, Pesan Moral, Tayangan, Visual.

\section{Pendahuluan}

Kemajuan televisi sebagai media massa dirasakan begitu cepat, hal ini dikarenakan televisi merupakan media massa yang paling dirasakan manfaatnya oleh masyarakat. Meskipun dari media massa yang ada, televisi merupakan media massa yang muncul pada era-era belakangan ini. Namun keberadaan media ini dinilai sangat efektif dan menarik perhatian dikalangan masyarakat luas. Hal ini disebabkan karena sifat media adalah audio visual yang mana tidak dimiliki media-media lain.

Munculnya televisi dalam kehidupan manusia tentunya menimbulkan suatu efek tertentu yang berdampak pada perubahan sosial dan kebudayaan. Kemampuan televisi dalam menarik perhatian massa menunjukkan media massa tersebut menguasai secara geografis dan sosiologis. ${ }^{1}$ Sehingga harus diakui bahwa televisi sangat besar pengaruhnya dalam membentuk sebuah pola pikir, pendapat umum dan pengembangan pengetahuan, televisi juga mampu mengubah sikap dan perilaku khalayak atau penontonnya. Hal tersebut sesuai dengan fungsi televisi secara universal adalah sebagai informasi (to inform), mendidik (to educate), menghibur (to entertain) dan mempengaruhi (to influence) yang pada kenyataannya sudah dipenuhi oleh semua stasiun televisi baik yang dikelola pemerintah maupun swasta. ${ }^{2}$ Melihat cepatnya perkembangan dan efektifitas dalam media televisi inilah, memaksa media-media televisi di Indonesia membuat beberapa tayangan-tayangan yang menarik simpati serta tayangan yang memberikan nilai-nilai positif dimasyarakat, dengan pengaruh tersebut maka muncullah tayangan adzan ditelevisi-televisi nasional sebagai tanda masuknya waktu sholat bagi ummat muslim.

Stasiun televisi swasta RCTI (Rajawali Citra Televisi Indonesia) merupakan stasiun televisi swasta pertama yang hadir di Indonesia, namun pada tahun 1993 media tersebut dinyatakan sebagai televisi yang paling banyak menayangkan tayangan anti sosial dengan persentase $54,96 \%$, adegan antisosial ini mencakup perkelahian, beberapa jenis kekerasan, gangguan terhadap orang lain serta sadisme. ${ }^{3}$ Hal tersebut terlihat berbeda pada beberapa tahun belakangan, televisi yang disaksikan oleh lebih dari 190,4 juta 1996), 27

${ }^{1}$ Wawan Kuswadi, Komunikasi Massa: Sebuah Ananlisis Media Televisi Jakarta: Rineka Cipta,

${ }^{2}$ Idi Subandi Ibrahim, Bercinta Dengan Televisi (Bandung: Remadja Rosdakarya, 1997), 97.

${ }^{3}$ Kuswandi, Komunikasi Massa, 62. 
pemirsa yang tersebar di 478 kota diseluruh Nusantara ini ${ }^{4}$, mampu hadir lebih mendidik dan menarik minat para pemirsanya, hal tersebut juga terlihat dalam tayangan adzan yang ditampilkan oleh televisi ini. Tayangan yang berdurasi lebih kurang empat menit ini mengandung banyak adegan yang seolah menjelaskan tentang nilai-nilai yang terkandung dalam kalimat adzan. Hal tersebut berbeda dengan kebanyakan televisi-televisi lain yang hanya mengedepankan teknik fotografi saja seperti: pemandangan alam, masjid, gambar orang adzan, dan lain sebagainya. Sehingga meskipun terdapat pesan-pesan dalam tayangannya namun tidak dapat dimengerti oleh khalayak secara umum.

Berangkat dari latar belakang tersebut, peneliti memutuskan untuk melakukan kajian yang lebih mendalam terkait pesan moral yang terkandung dalam tayangan adzan maghrib RCTI versi tahun 2014-2015, dengan menggunakan analisis semiotika Roland Barthes. Sebagai titik akhir dari penelitian ini, maka peneliti merumuskan masalah tentang bagaimana pesan moral yang terkandung dalam tayangan adzan maghrib di RCTI? Hal tersebut bertujuan untuk mengetahui pesan moral yang terkandung dalam tayangan adzan maghrib di RCTI versi tahun 2014-2015.

\section{Metode Penelitian}

Metode penelitian yang digunakan dalam penelitian ini adalah analisis semiotik dengan model Roland Barthes, Barthes dalam pemikirannya membagi tingkatan makna menjadi dua tingkatan yaitu, Pertama makna denotasi, istilah denotasi ini adalah tingkatan pertama yang bersifat objektif dan dapat diberikan terhadap lambang-lambang, dengan cara mengaitkan secara langsung antara lambang dengan realitas atau gejala yang ditunjuk. Kedua makna konotasi, konotasi merupakan makna-makna yang dapat diberikan pada lambang-lambang dengan mengacu pada nilai-nilai budaya yang karenanya berada pada tingkatan kedua. Secara panjang lebar Barthes mengulas tentang sistem pemaknaan tataran ke-dua, yang dibangun di atas sistem lain yang telah ada sebelumya. Dalam sistem ke-dua inilah Barthes menyebutnya dengan konotatif atau sistem pemaknaan pada tataran pertama. Untuk melanjutkan studi Hjelmslev, Barthes menciptakan peta tentang bagaimana tanda bekerja: ${ }^{5}$

Tabel 1 : Peta Tanda Roland Barthes

\begin{tabular}{|l|l|}
\hline 1. Signifier (penanda) & 2. Signified (petanda) \\
\hline 3. Denotative sign (tanda denotatif) & \\
\hline 4. conotative signifier (penanda konotatif) & 5. conotative signified (petanda konotatif) \\
\hline 6. conotative sign (tanda konotatif) & \\
\hline
\end{tabular}

\footnotetext{
${ }^{4}$ Rajawali Citra Televisi Indonesia, Profile Perusahaan, dalam http://www.rcti.tv/profile/view/1/Profile\%20Perusahaan, diakses pada tanggal 09 Maret 2015 pukul 18:13 WIB.

5 Alex Sobur, Semiotika Komunikasi, (Bandung: Remaja Rosdakarya, 2006), 69.
} 
Dari peta tanda Barthes di atas, terlihat bahwa tanda denotatif (3), terdiri dari penanda (1) dan petanda (2). Akan tetapi, pada saat yang sama, tanda denotatif adalah juga penanda konotatif (4). Sehingga dalam konsep Roland Barthes, tanda konotatif tidak sekedar memiliki makna tambahan, akan tetapi juga mengandung kedua bagian tanda donotatif yang melandasi keberadaannya.

\section{Hasil dan Pembahasan}

Pada bagian ini, peneliti akan memaparkan analisis semiotik dengan model Roland Barthes, analisis model Roland Barthes ini akan ditampilkan dalam tabel sesuai indikator moral yang menjadi benang merah pada penelitian ini. Moral dalam defenisi lainnya adalah sebagai akhlak yang merupakan perilaku atau perangai yang baik. Menurut As-Suhrawadi, kaum sufi merupakan golongan manusia yang paling besar bagiannya dalam meneladani Rasulullah dan paling berkewajiban melesatarikan sunnah-sunnahnya serta berakhlak sebagaimana akhlak Rasulullah. ${ }^{6}$ Akhlak terpuji yang nampak pada tokoh utama dalam tayangan adzan maghrib di RCTI versi 2014/2015. Berikut penjelasannya:

\section{Sifat Tawadhu'}

Sifat tawadhu' memiliki tujuan untuk melatih sikap rendah hati didalam diri manusia serta tidak melakukan perlawanan terhadap sebuah kebenaran. Saat seseorang telah menghilangkan sikap tawadhu' dalam dirinya, maka yang akan timbul adalah kesombongan, sombong adalah menolak kebenaran dan merendahkan manusia. ${ }^{7}$ Sehingga Tawadhu' memerintahkan pelakunya untuk selalu bersikap sopan kepada orang lain dan menyapa atau menjawab sapaan orang lain saat bertemu. Di dalam tayangan adzan maghrib di RCTI versi 2014/2015 terdapat sifat tawadhu'. Deskripsi data tawadhu' meliputi dalam tabel-tabel berikut:

\section{Tabel 2. Semiotika Roland Barthes}

\begin{tabular}{|c|c|c|c|}
\hline \multirow[t]{2}{*}{ Denotasi } & Signifier & Signified & \\
\hline & $\begin{array}{l}\text { Pada detik 00:00:22, tampak pada gambar } \\
\text { 1, seorang anak laki-laki berbaju putih } \\
\text { dengan mengenakan rompi merah sedang } \\
\text { mencium tangan seorang wanita yang } \\
\text { berbaju kuning serta memakai tutup } \\
\text { kepala.Anak laki-laki tersebut tampak } \\
\text { hendak pergi dengan membawa buku dan } \\
\text { tas ransel dipunggungnya. Di bagian bawah } \\
\text { dalam gambar tersebut terdapat } \\
\text { tulisan Allah dengan huruf arab berwarna } \\
\text { putih. }\end{array}$ & $\begin{array}{l}\text { Seorang anak laki-laki yang merupakan } \\
\text { Bramantyo sedang mencium tangan } \\
\text { perempuan tua berbaju kuning sebelum } \\
\text { ia pergi ke sekolah. Kalimat Allah } \\
\text { merupakan bagian dari kalimat Allabu } \\
\text { akbar dalam adzan, yang memiliki arti } \\
\text { Allah Maha Besar. }\end{array}$ & \\
\hline Konotasi & \multicolumn{2}{|c|}{ Signifier } & Signified \\
\hline
\end{tabular}

${ }^{6}$ Mu Fauqi Hajjaj, Tasawuf Islam \& Akhlak, Terj. Kamran As'at Irsyady \& Fakhri Ghazali, (Jakarta: Amzah,2011), 313.

7 Amr Khaled, Buku Pintar Akblak, terj. Fauzi Faisal Bahreisy, (Jakarta: Zaman, 2010). 292. 


\begin{tabular}{|l|l|c|}
\hline $\begin{array}{l}\text { Kalimat Allabu akbar merupakan kalimat yang mampu menggugah atau mampu } \\
\text { menggetarkan hati orang-orang yang beriman. Sehingga apabila kalimat ini didengar oleh } \\
\text { Orang yang benar-benar beriman maka ia akan berusaha untuk rendah diri serta } \\
\text { membangun rasa hormat menghormati. Bentuk penghormatan yang nyata adalah dengan } \\
\text { bersalaman dan mencium tangan orang tua ketika bertemu dengan mereka. }\end{array}$ & $\begin{array}{c}\text { moral } \\
\text { dengan } \\
\text { tafifat }\end{array}$ \\
\hline Tanda konotasi Tawadhu' kepada ibu. & \\
\hline
\end{tabular}

Pada level denotasi menjadi signifier adalah seluruh tanda nonverbal dan tanda verbal yang terlihat dalam tabel 2. Tampak pada gambar saat seorang anak laki-laki yang berbaju putih dengan memakai rompi merah sedang mencium tangan seorang perempuan tua yang menggunakan baju kuning dan memakai tutup kepala. Pada gambar juga terlihat anak laki-laki tersebut sedang memegang sebuah buku dan tas ransel yang berada di punggungnya. Selain itu di dalam gambar 1 juga terdapat tulisan Allah berwarna putih dengan menggunakan huruf Arab.

Signifier dalam level konotasi di sini adalah makna lain yang terkandung dalam tanda verbal dan tanda nonverbal yang dijelaskan pada level denotasi. Tanda non-verbal pada gambar 1, seperti yang dijelaskan di atas pada level denotasi bahwa seorang laki- laki yang merupakan Bramantyo sedang mencium tangan seorang perempuan tua, perempuan tersebut adalah ibu dari Bramantyo. Bila dilihat dari mitos yang merupakan bagian dari analisis Roland Barthes, maka mencium tangan orang yang lebih tua usianya atau pun seorang ibu adalah sebuah kebiasaan dan menjadi budaya bangsa indonesia. Sementara bila dikaitkan dengan indikator tawadhu' dalam penelitian ini, maka kegiatan bersalaman atau mencium tangan orang yang lebih tua termasuk dalam indikator tawadhu' yang memiliki tujuan untuk menghilangkan kesombongan dalam diri seseorang. Sedangkan tulisan Arab Allah yang berwarna putih merupakan tanda kesucian yang diperlihatkan dari kalimat tersebut.

Pada tanda verbal dalam durasi detik ke-22, kalimat Allah yang merupakan bagian dari kalimat Allahu akbar pada kalimat adzan, memiliki arti Allah maha besar. Namun apabila dalam level konotasi, maka arti kalimat adzan tersebut mengandung maksud bahwa kalimat Allahu akbar merupakan kalimat menggugah atau mampu menggetarkan hati orang-orang yang beriman, sehingga apabila telah mengakui keimanan dalam diri seseorang, maka orang tersebut tidak akan melakukan perbuatan yang menimbulkan kesombongan terhadap dirinya.

Tabel 3. Semiotika Roland Barthes

\begin{tabular}{|c|c|c|}
\hline Denotasi & Signifier & Signified \\
\hline & $\begin{array}{l}\text { Pada menit 00:02:56, tampak pada gambar } 2 \text {, } \\
\text { serorang laki laki berkulit puth dan berbaju } \\
\text { kemeja putih sedang tersenyum dengan } \\
\text { serorang laki-laki beruban. Dibagian bawah } \\
\text { gambar tersebut terdapat tulisan Arab hay 'alal } \\
\text { faläh berwarna putih serta tepat dibawah tulisan } \\
\text { arab tersebut tampak tulisan "mari meraih } \\
\text { kemenangan" berwarna putih. }\end{array}$ & $\begin{array}{l}\text { Laki-laki berbaju kemeja putih adalah } \\
\text { Bramantyo yang sedang menyapa laki-laki tua } \\
\text { dengan kalimat salam. Kalimat hayya 'alal faläh } \\
\text { adalah bagian dari kalimat adzan yang } \\
\text { memiliki arti "mari bersama meraih } \\
\text { kemenangan". }\end{array}$ \\
\hline Konotasi & Signifier & Signified \\
\hline
\end{tabular}




\begin{tabular}{|l|l|r|}
\hline $\begin{array}{l}\text { Kalimat salam bagi orang yang beriman atau orang yang beragama islam } \\
\text { adalah dengan kalimat assalamualaikum warohmatullah wabarokatuh, kalimat }\end{array}$ & $\begin{array}{c}\text { Pesan dengan } \\
\text { denoral } \\
\text { sifat } \\
\text { tersebut telah menjadi kalimat yang selalu diucapkan oleh umat muslim saat } \\
\text { bertemu dengan saudaranya. Kalimat hayy 'alal faläh adalah kalimat yang } \\
\text { berada di posisi kelima dari adzan yang menjadi tujuan akhir dari seorang } \\
\text { yang beriman. Kemenangan atau al-faläh adalah tujuan dari seluruh hamba- } \\
\text { Nya, yang mana salah satu bentuk keimanan adalah dengan berusaha untuk } \\
\text { rendah hati dan tidak berlaku sombong kepada orang lain serta } \\
\text { mengucapkan salam saat akan berpisah dan bertemu dengan seseorang. }\end{array}$ \\
\hline Tanda konotasi Tawadhu' kepada orang tua. & \\
\hline
\end{tabular}

Pada level denotasi menjadi signifier adalah seluruh tanda nonverbal dan tanda verbal yang terlihat pada tabel 3. Tampak pada gambar saat seorang laki-laki berkulit putih dan berbaju kemeja putih yang merupakan Bramantyo sedang mengucapkan kalimat assalamualaikum kepada seorang laki-laki tua yang berdiri dilorong rumah sakit. Selain itu, pada gambar satu juga terdapat tulisan Arab hayya 'alal falāh yang merupakan bagian dari kalimat adzan, serta dibawah kalimat Arab terdapat arti dari kalimat tersebut.

Signifier dalam level konotasi di sini adalah makna lain yang terkandung dalam tanda verbal dan tanda nonverbal yang dijelaskan pada level denotasi. Tanda non-verbal pada gambar 2, seperti yang dijelaskan di atas pada level denotasi bahwa seorang laki- laki yang menggunakan baju kemeja putih adalah Bramantyo yang sedang mengucapkan kalimat salam kepada laki-laki tua yang berada di depannya, mengucapkan kalimat salam menjadi tolak ukur dalam menentukan pesan moral dalam adegan tersebut. Bila dilihat dari mitos yang merupakan bagian dari analisis Roland Barthes, maka mengucapkan salam antar sesama, adalah bentuk kebiasaan orang-orang di dunia ini, namun kalimat salam yang dilontarkan juga terdapat perbedaan. Bagi kalangan umat islam, terutama di Indonesia kalimat assalamualaikum warohmatullah wabarokatub tidaklah menjadi hal yang baru ditelingan mereka. Sehingga mengucapkan kalimat salam dianggap sebagai kesopanan atau akhlak yang baik yang ditampilkan seseorang saat bertemu. Dalam sika tawadhu' mengucapkan kalimat salam atau bertegur sapa kepada orang lain adalah sebuah anjuran untuk melatih manusia terhindar dari sifat kesombongan. Sedangkan tulisan Arab hayya 'alal faläh beserta artinnya yang berwarna putih merupakan tanda kesucian yang diperlihatkan dari kalimat tersebut.

Pada tanda verbal dalam durasi menit ke-02 detik ke-56, terdapat tanda verbal kalimat hayya 'alal falāh yang merupakan bagian dari kalimat adzan yang menjadi audio dalam tayangan tersebut. Pada level konotasi, kalimat hayya 'alal falāh merupakan kalimat adzan yang berada di posisi kelima, dalam al-qur'an terdapat beberapa indikator orang peraih al- faläh yang mana salah satunya adalah keimanan. Orang yang memiliki keimanan, maka ia akan selalu tunduk kepada Allah dan selalu menjalankan perintahnya dan menghargai penciptaannya, maka secara sadar orang yang memiliki keimanan akan berusaha untuk rendah hati kepada sesama manusia serta menghormati mereka sebagai ciptaan Allah. 
Tabel 4. Semiotika Roland Barthes

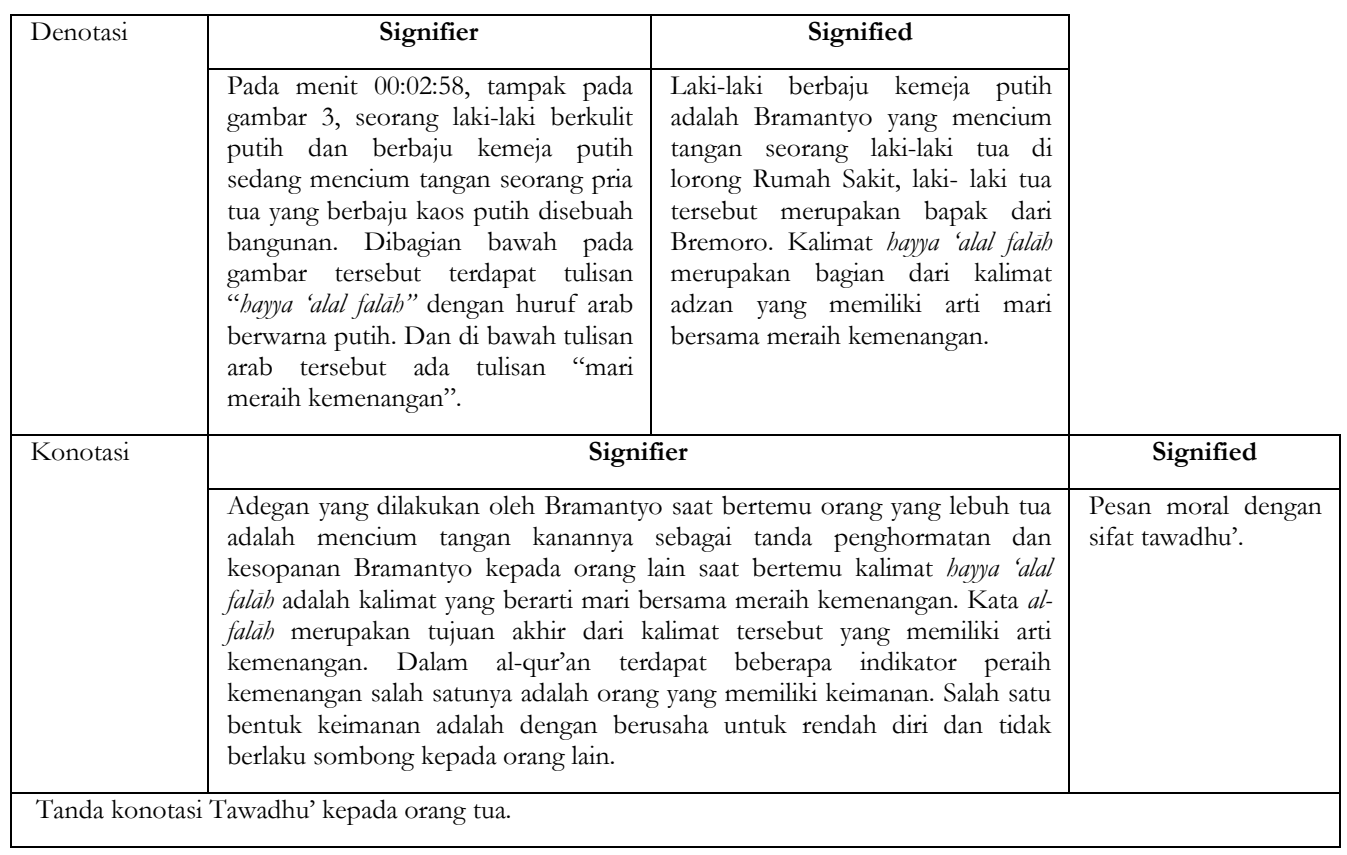

Pada level denotasi menjadi signifier adalah seluruh tanda nonverbal dan tanda verbal yang terlihat pada tabel 4. Tampak pada gambar saat seorang laki-laki berbaju kemeja putih yang sedang mencium tangan kanan seorang pria tua disebuah bangunan. Selain itu di dalam gambar 3 juga terdapat tulisan hayya 'alal faläh berwarna putih dengan menggunakan huruf Arab beserta tulisan mari bersama meraih kemenangan. Signifier dalam level konotasi di sini adalah makna lain yang terkandung dalam verbal dan nonverbal yang dijelaskan pada level denotasi.

Tanda non-verbal dari tabel 4, sebagaimana yang dipaparkan di atas pada level denotasi bahwa seorang laki-laki berbaju kemeja putih sedang mencium tangan seorang laki-laki tua disebuah bangunan, adegan mencium tangan seorang laki-laki tersebut merupakan tolak ukur dalam indikator tawadhu'. Sikap tawadhu' merupakan prilaku seseorang untuk selalu rendah hati dan tidak meninggikan kesombongan, Bila dilihat dari mitos yang merupakan bagian dari analisis Roland Barthes, maka adegan mencium tangan tersebut, menurut kebiasaan dimasyarakat Indonesia adalah tanda penghormatan dan kesopanan seseorang kepada orang lain.

Masyarakat Indonesia sering mencium tangan orang yang lebih tua saat bertemu atau berpisah dengan orang tersebut. Sedangkan tulisan Arab hayya alal faläh yang berwarna putih merupakan tanda kesucian yang diperlihatkan dari kalimat tersebut. Pada tanda verbal dalam durasi menit ke-02 detik ke-58, terdapat tanda verbal kalimat hayya 'alal falāh yang merupakan bagian dari kalimat adzan yang menjadi audio dalam tayangan tersebut. kalimat ini tidak hanya mengandung arti mari meraih kemenangan, tapi kata alfalāh adalah tujuan akhir dari setiap hamba yang telah malakukan ibadah sholat. Salah satu 
peraih kemenangan dalam al-qur'an adalah orang yang memiliki keimanan. Ketika seseorang telah memiliki keimanan maka ia akan menyadari akan kerendahan dirinya dan berusaha untuk rendah hati saat bersama orang lain, seprti hasil wawancara di bawah ini:

"Bersalaman sebenarnya tradisi negara indonesia, jadi dari adegan tersebut kami itu pengen memunculkan budaya indonesia bahwa ketika bertemu dengan orang yang lebih tua maka orang indonesia bersalaman. sehingga dengan karakter bramantyo yang sopan maka kami ingin memperlihatkan keseharian orang indonesia saat bertemu dengan orang lain itu seperti apa"s

\section{Sifat Lemah Lembut}

Perilaku lemah lembut yaitu prilaku yang selalu memberikan pujian dan sanjungan kepada orang lain. Dalam prilaku ini, memberikan kelembutan kepada orang lain adalah upaya manusia mendapatkan kecintaan Allah kapadanya. Lemah lembut bukan berarti tidak memiliki kemantapan diri saat bertindak, namun sebuah upaya menghindari perbuatan terburu-buru dan emosional agar tidak menyakiti antar sesama. Di dalam tayangan adzan maghrib di RCTI versi 2014/2015 terdapat sifat lemah lembut. Deskripsi data lemah lembut meliputi dalam tabel-tabel berikut:

\section{Tabel 5. Semiotika Roland Barthes}

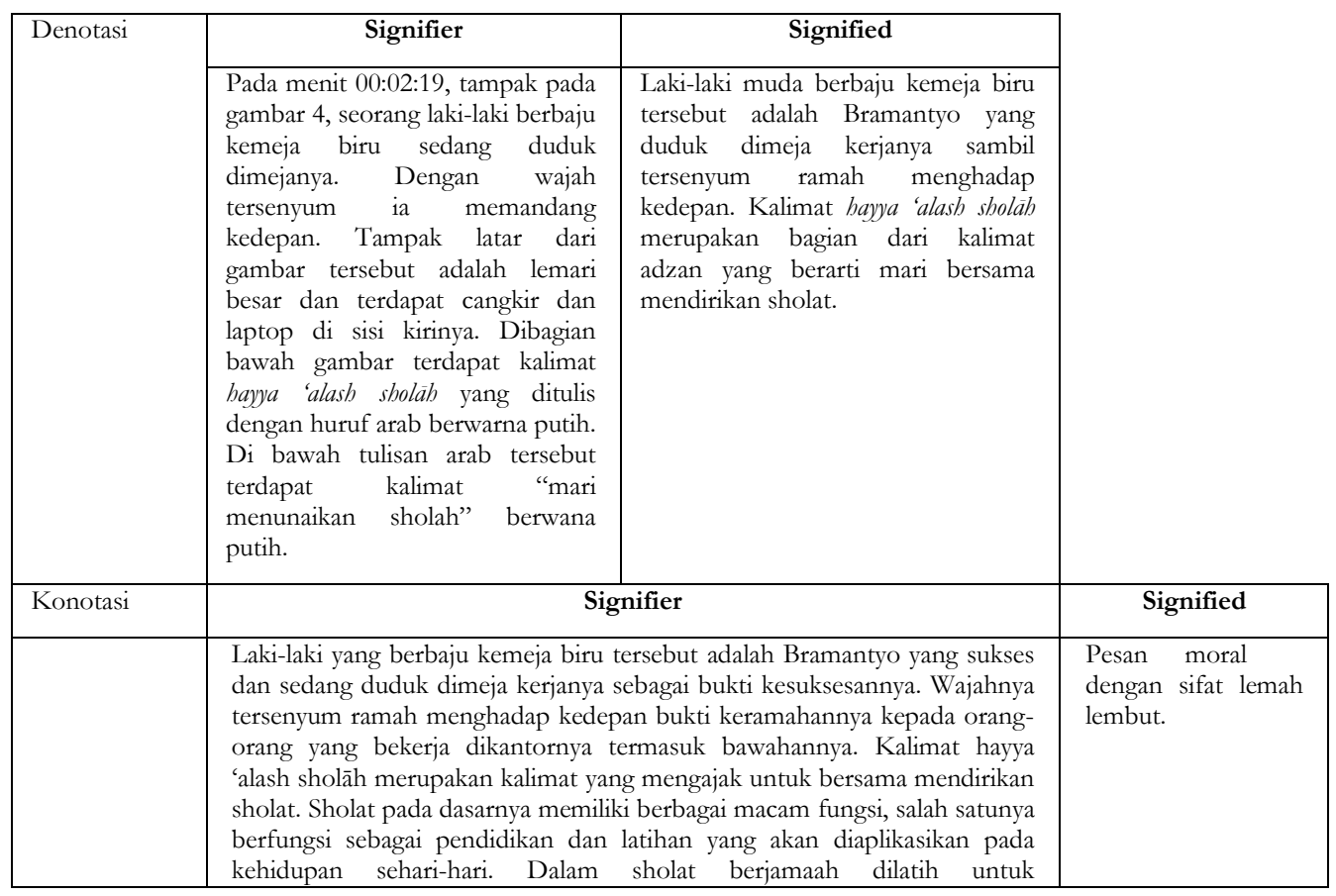

8 Wawancara dengan Gandes Krisantyo, Kreatif Produksi Tayangan Adzan RCTI, 17 September 2105. 


\begin{tabular}{|l|l|l|}
\hline & $\begin{array}{l}\text { berkomunikasi yang antar umat. Sehingga orang yang telah melakukan } \\
\text { sholat harapannya mampu berinteraksi yang baik kepada orang-orang } \\
\text { disekitarnya termasuk }\end{array}$ & \begin{tabular}{l} 
kepada bawahan dikantor. \\
\hline Tanda konotasi lemah lembut kepada bawahan.
\end{tabular} \\
\hline
\end{tabular}

Pada level denotasi menjadi signifier adalah seluruh tanda nonverbal dan tanda verbal yang terihat dalam tabel 5. Tampak pada gambar saat seorang laki-laki muda berbaju biru sedang duduk tersenyum di sebuah meja, dengan berlatar lemari besar dan terlihat cangkir putih berada disisi kanannya serta leptop yang berada disis kirinya. Selain itu dibagian bawah dalam gambar 4 tersebut juga terdapat tulisan Arab hayya 'alash sholāh beserta artinya yaitu mari bersama menunaikan sholat, yang berwarna putih. Signifier dalam level konotasi di sini adalah makna lain yang terkandung dalam verbal dan nonverbal yang dijelaskan pada level denotasi. Tanda non-verbal dari tabel 5, sebagaimana yang dijelaskan di atas pada level denotasi bahwa seorang laki-laki yang memakai baju kemeja rapi berwarna biru tersebut adalah Bramantyo yang sedang duduk di meja kerjanya. Bila dilihat dari mitos yang merupakan bagian dari analisis Roland Barthes, maka penilaiannya bahwa kerapian yang ditunjukkan oleh Bramantyo akan menginterpretasikan bawah dirinya adalah sebagai pemimpin perusahaan atau orang yang telah sukses dalam karirnya. Kemudian, dengan wajah yang tersenyum menghadap kedepan adalah bentuk keramahan Bramantyo kepada orang lain atau kepada bawahannya. Sedangkan tulisan Arab bayya 'alash sholäh dan artinya diberikan warna putih memiliki artian bahwa putih adalah suci, dan kalimat tersebut dianggap kalimat yang suci.

Pada tanda verbal dalam durasi menit ke-02 detik ke-19, terdapat tanda verbal kalimat hayya 'alash sholäh yang merupakan bagian dari kalimat adzan yang menjadi audio dalam tayangan adzan tersebut. Kalimat ini yang dalam arti sebenarnya adalah ajakan untuk mendirikan sholat. Bila dilakukan pengkajian secara konotasi, maka sholat memiliki banyak fungsi, salah satunya adalah fungsi pendidikan dan latihan. Sebagai fungsi pendidikan dan latihan, sholat memiliki beberapa nilai-nilai yang dapat diaplikasikan dalam kehidupan sehari-hari, salah satunya adalah nilai kepemimpinan. Pemimpin yang baik adalah pemimpin yang memiliki jiwa tenang sebagaimana tenangnya sholat yang selalu didirikan, tidak mengambil keputusan dengan emosi yang mengakibatkan kesengsaraan orang disekitarnya.

\section{Kasih Sayang}

Kasih sayang adalah proses tumbuhnya rasa saling mengerti dan mencintai dalam sebuah kedekatan antar seseorang atau kelompok lainnya. Bentuk kasih sayang yang dibangun oleh seseorang atau kelompok adalah dengan mengenali dan memahami sesama. Hakekat kasih sayang yang bening dan bersih membuat seseorang yang memiliki rasa kasih sayang tidak ingin untuk saling menyakiti, namun berusaha saling menyemangati. Di dalam tayangan adzan maghrib di RCTI versi 2014/2015 terdapat sifat kasih sayang. Deskripsi data kasih sayang meliputi dalam tabel-tabel berikut: 
Tabel 6. semiotika Roland Barthes

\begin{tabular}{|c|c|c|c|}
\hline \multirow[t]{2}{*}{ Denotasi } & Signifier & Signified & \\
\hline & $\begin{array}{l}\text { Pada menit } 00: 02: 24 \text {, tampak pada } \\
\text { gambar } 5 \text {, seorang laki-laki berbaju } \\
\text { kemeja putih, wajahnya tersenyum } \\
\text { tipis sambil memasukkan sesuatu } \\
\text { kedalam mulut perempuan tua yang } \\
\text { sedang terbaring. }\end{array}$ & $\begin{array}{l}\text { Seorang laki-laki berbaju kemeja putih } \\
\text { yang merupakan Bramantyo sedang } \\
\text { member obat kepada ibunya, dengan } \\
\text { senyuman yang tipis ia menyuapkan obat } \\
\text { untuk ibunya yang sedang terbaring.. }\end{array}$ & \\
\hline \multirow[t]{2}{*}{ Konotasi } & \multicolumn{2}{|c|}{ Signifier } & Signified \\
\hline & \multicolumn{2}{|c|}{$\begin{array}{l}\text { Laki-laki berbaju kemeja putih adalah Bramantyo yang sedang memberikan obat } \\
\text { kepada ibunya yang sedang terbaring sakit, dengan pelan ia menyuapkan obat } \\
\text { tersebut. Berbaktinya Bramantyo kepada ibunya, diwujudkan dalam bentuk } \\
\text { perawatan yang penuh kasih sayang. } \\
\text { Pesan untuk menjadi anak yang sayang kepada orang tua, meskipun orang tua } \\
\text { sudah terbaring di rumah sakit, namun sebagai anak harus merawat dengan tulus. }\end{array}$} & $\begin{array}{l}\text { Pesan moral } \\
\text { dengan sifat kasih } \\
\text { sayang. }\end{array}$ \\
\hline
\end{tabular}

Pada level denotasi menjadi signifier adalah seluruh tanda nonverbal dan tanda verbal yang telihat pada tabe 6. Tampak seorang laki-laki muda berbaju kemeja putih sedang menyuapkan sesuatu kepada perempuan tua yang sedang terbaring, dengan wajah yang tersenyum, anak laki-laki tersebut memasukkan makanan kadalam mulut seorang perempuan tua tersebut. Signifier dalam level konotasi di sini adalah makna lain yang terkandung dalam tanda verbal dan nonverbal yang dijelaskan pada level denotasi. Tanda non-verbal dari gambar 5, sebagai mana yang dipaparkan di atas pada level denotasi bahwa seorang laki- laki berbaju kemeja putih atau Bramantyo sedang memasukkan makanan ke dalam mulut seorang perempuan tua yaitu ibunya dengan wajah yang tersenyum. Adegan yang ditampilkan di atas adalah bentuk kasih sayang antara anak dan ibu, sebab bila dilihat dari mitos yang merupakan bagian dari analisis Roland Barthes, maka senyum tipis laki-laki tersebut menandakan sebuah keikhlasan dalam merawat dan menjaga ibu, kemudian adegan yang memberikan makanan kedalam mulut ibu adalah bentuk kasih sayang yang tulus dari hati seorang Bramantyo kepada ibu. Sehingga dalam level konotasi adegan yang diperlihatkan oleh Bramantyo kepada ibunya adalah bentuk representasi dari sifat kasih sayang dalam bentuk merawat dan menyuapkan makanan kepada ibunya. Hal ini dapat di lihat dari hasil wawancara sebagai berikut:

"Jika dilihat dari awalkan sudah jelas, bahwa Bramantyo dari kecilnya sudah hormat kepada ibunya, dia sama ibunya sayang. nah ini dia sampai besar pun ia masih memperlihatkan rasa hormat itu kepada ibunya dan rasa sayang kepada ibunya dan dia menjadi anak yang sholeh dimata ibunya. makanya ia memperlakukan ibunya seperti itu, meskipun ia sudah besar, sudah sukses, tapi ia tetap menghormati dan inget kepada ibunya".?

9 Wawancara dengan Gandes Krisantyo, Kreatif Produksi Tayangan Adzan RCTI, 17 September 2105. 


\section{Beramal Shaleh}

Beramal shaleh adalah anjuran islam sebagai pembuktian diri dari keimanan yang dinyatakan oleh manusia, aksi atau amal shaleh adalah bentuk kerja nyata terhadap amalan-amalan yang selalu dilakukan. Keimanan bukan hanya menyatakan kesanggupan menjalankan perintah Allah, tetapi juga kesanggupan diri untuk bermanfaat bagi orangorang disekitar. Tak hanya harta yang harus dijadikan amal shaleh kepada sesama manusia, namun dalam bentuk jasa, petunjuk serta pertolongan lain yang dibutuhkan oleh orang lain. Sikap mementingkan orang lain tentu saja merupakan indikator kesucian nafsu diri dan bukti perlawanan terhadap kecendrungan kikir dan bakhil sehingga beramal shaleh merupakan jalan kebahagaian dan kesuksesan. Di dalam tayangan adzan maghrib di RCTI versi 2014/2015 terdapat sifat beramal shaleh. Deskripsi data beramal shaleh meliputi tanda yang ditampilkan dalam tabel-tabel berikut:

Tabel 7. Semiotika Roland Barthes

\begin{tabular}{|c|c|c|c|}
\hline \multirow[t]{2}{*}{ Denotasi } & Signifier & Signified & \\
\hline & $\begin{array}{l}\text { Pada menit } 00: 03: 01 \text {, tampak pada } \\
\text { gambar 6, seorang pemuda berbaju } \\
\text { kemeja putih sedang memandang } \\
\text { wajah seorang laki- laki tua yang } \\
\text { sedang memegang kertas } \\
\text { didepannya. } \\
\text { Sementara laki-laki tua yang } \\
\text { memakai baju kaos putih tersebut } \\
\text { terlihat menunduk melihat kertas } \\
\text { putih yang ia pegang. }\end{array}$ & $\begin{array}{l}\text { Pemuda berbaju kemeja putih adalah } \\
\text { Bramantyo yang berada dilorong rumah } \\
\text { sakit dengan seorang laki-laki tua yang } \\
\text { merupakan bapak dari Bremoro, } \\
\text { Bramantyo menawarkan diri untuk } \\
\text { menyumbangkan darahnya untuk } \\
\text { Bremoro yang sedang membutuhkan } \\
\text { darah AB. }\end{array}$ & \\
\hline \multirow[t]{2}{*}{ Konotasi } & \multicolumn{2}{|c|}{ Signifier } & Signified \\
\hline & \multicolumn{2}{|c|}{$\begin{array}{l}\text { Pesan untuk semua orang agar selalu berbuat baik kepada orang lain, meskipun } \\
\text { orang tersebut telah terlebih dahulu berbuat jahat kepada mu. }\end{array}$} & $\begin{array}{l}\text { Pesan moral } \\
\text { dengan sifat } \\
\text { beramal shaleh. }\end{array}$ \\
\hline
\end{tabular}

Pada level denotasi menjadi signifier adalah seluruh tanda nonverbal dan tanda verbal yang terlihat pada tabel 7. Tampak pada gambar saat seorang pemuda berbaju kemeja putih sedang melihat wajah seorang laki-laki tua yang sedang memegang kertas didepannya. Pemuda berbaju putih tersebut terlihat dengan sedikit menunduk sementara laki-laki tua tersebut tertunduk melihat kertas yang ada di ganggamannya.

Signifier dalam level konotasi di sini adalah makna lain yang terkandung dalam tanda verbal dan nonverbal yang dijelaskan pada level denotasi. Tadan non-verbal dari gambar 6, sebagaimana yang dijelaskan pada level denotasi di atas bahwa seorang laki- laki berbaju kemeja putih sedang berhadapan dengan seorang laki-laki tua berbaju kaos, mereka sama-sama tertunduk, dengan penuh simpati Bramantyo yang menggunakan baju kemeja putih memandang wajah laki-laki tua tersebut. Bila dilihat dari mitos yang merupakan bagian dari analisis Roland Barthes, maka adegan ini menginterpretasikan orang yang penuh kebimbangan dan berharap adanya pertolongan, sedangkan Bramantyo yang melihat penuh simpati dan berusaha untuk memberikan pertolongan kepada laki- 
laki tua yang merupakan bapak dari Bremoro. Sehingga bila dikaitkan dengan sikap beramal shaleh, maka adegan tersebut memperlihatkan bahwa Bramantyo berusaha menjadi orang yang bisa bermanfaat bagi Bremoro. Maka dalam level konotasi, hal ini merupakan bentuk sikap beramal shaleh yang ditunjukkan oleh Bramantyo kepada bapak dari Bremoro dengan kesediannya untuk mendonorkan darahnya untuk Bremoro.

\section{Sabar}

Manusia hidup ditengah-tengah berbagai macam permasalahan dan semua permasalahan tersebut harus bisa dikendalikan. Kesabaran atau sifat sabar merupakan obat yang ampuh untuk menghadapi permasalahan, sabar adalah bentuk pengendalian emosi dan perasaan yang buruk. Sebagai manusia ciptaan Allah kita diuji kesabaran dengan berbagai perintah dan larangan-Nya, sementara kita sebagai manusia yang bersosial juga diuji kesabaran dengan menghadapi pergaulan antar sesama manusia, dan kita sebagai manusia yang lemah juga diuji kesabaran dengan berbagai macam cobaan. Meski demikian, pengendalian nafsu dengan sabar akan melahirkan prilaku optimis, mantap dan penuh tanggung jawab. Di dalam tayangan "Adzan Maghrib RCTI versi 2014-2015" terdapat sifat sabar. Deskripsi data beramal shaleh meliputi tanda yang ditampilkan dalam tabel-tabel berikut:

Tabel 8. Semiotika Roland Barthes

\begin{tabular}{|c|c|c|c|}
\hline Denotasi & Signifier & Signified & \\
\hline & $\begin{array}{l}\text { Pada detik 00:00:42, tampak pada gambar 7, } \\
\text { seorang anak laki- laki kecil berbaju kemeja } \\
\text { putih dan memakai rompi merah sedang } \\
\text { duduk dan matanya menatap kedepan } \\
\text { dengan mulut tertutup rapat. } \\
\text { Dibagian bawah pada gambar tersebut } \\
\text { terdapat tulisan "asyhadu anlà iläha illalläb" } \\
\text { dengan huruf arab berwarna putih. Tepat di } \\
\text { bawah huruf arab tersebut tampak tulisan } \\
\text { "aku bersaksi bahwa tiada tuhan selain } \\
\text { Allah". }\end{array}$ & $\begin{array}{l}\text { Anak laki-laki kecil berbaju kemeja putih } \\
\text { tersebut adalah Bramantyo yang sedang } \\
\text { berada didalam mobil sekolah. Matanya } \\
\text { berkaca-kaca yang menatap kedepan dengan } \\
\text { mulut yang tertutup rapat. } \\
\text { Kalimat "asyhadu anlā iläha illalläh" } \\
\text { merupakan bagian dari kalimat adzan, yang } \\
\text { memiliki arti aku bersaksi tiada tuhan selain } \\
\text { Allah. }\end{array}$ & \\
\hline \multirow[t]{2}{*}{ Konotasi } & \multicolumn{2}{|c|}{ Signifier } & Signified \\
\hline & \multicolumn{2}{|c|}{$\begin{array}{l}\text { Seorang laki-laki yang merupakan Bramantyo sedang menahan amarahnya, karena ia telah } \\
\text { diganggu oleh temannya sendiri. Mulut tertutup rapat dan mata memandang kedepan } \\
\text { merupakan ekspresi dari seorang anak kecil yang tidak ingin melawan saat ia diperlakukan } \\
\text { tidak baik oleh temannya. } \\
\text { Kalimat asyhadu anlä iläha illalläh merupakan kalimat yang berada diurutan pertama dalam } \\
\text { kalimat syahadat. Kalimat ini merupakan bukti awal dari keimanan seseorang. Sehingga } \\
\text { dalam pengamalan kalimat ini mampu meyakini bahwa Allah merupakan dzat yang } \\
\text { sempurna dan menimbulkan sikap pasrah saat kalimat ini diucapkan. Sikap pasrah akan } \\
\text { terbentuk dalam sikap sabar, dengan kesabaran seseorang mampu menahan dirinya dari } \\
\text { perbuatan yang tercela. }\end{array}$} & $\begin{array}{l}\text { Pesan moral } \\
\text { dengan sifat sabar. }\end{array}$ \\
\hline
\end{tabular}


Pada level denotasi menjadi signifier adalah seluruh tanda nonverbal dan tanda verbal yang terlihat pada tabel 8. Tampak pada gambar saat seorang anak laki-laki yang memakai baju putih dan rompi merah sedang duduk dengan mata melihat kedepan dan mulut tertutup. Sementara dibagian bawah gambar terdapat tulisan asyhadu anlā ilāha illallăh beserta dengan tulisan aku bersaksi tiada tuhan selain Allah yang berwarna putih.

Signifier dalam level konotasi di sini adalah makna lain yang terkandung dalam tanda verbal dan tanda nonverbal yang dijelaskan pada level denotasi. Tanda non-verbal dari tabel 8, sebagaimana yang dijelaskan pada level denotasi diatas bahwa seorang anak laki-laki yang berada dimobil sekolah terlihat menahan amarahnya saat ia telah diusir oleh temannya untuk pindah kebelakang. Bila dilihat dari mitos yang merupakan bagian dari analisis Roland Barthes, maka wajah yang melihat kedepan tersebut dan mata yang sedikit berkaca-kaca merupakan cara anak kecil untuk menahan emosinya, hal lain adalah, anak kecil saat di ganggu oleh temannya yang berbadan besar akan berusaha sabar dan tidak melakukan perlawanan. Kemudian dibagian bawah gambar terdapat tulisan Arab asybadu anlà ilāha illallāh yang berwarna putih menandakan bahwa kalimat tersebut adalah kalimat yang mengandung kesucian.

Pada tanda verbal dalam durasi detik ke-42, terdapat tanda verbal kalimat asyhadu anlā ilāha illallāh yang merupakan bagian dari kalimat adzan yang menjadi audio dalam tayangan adzan maghrib tersebut. Pada level konotasi kalimat asyhadu anlā ilāha illallāh merupakan bagian pertama dalam kalimat syahadat yang mampu membuktikan keimanan seseorang. Dalam pengamalan kalimat ini mampu meyakinkan pembacanya akan kekuasaan Allah dan menimbulkan sikap pasrah dan patuh kepada Allah. Kepasrahan dan kepatuhan kepada Allah mampu melatih hamba-Nya untuk sabar dan menyerahkan segala sesuatu yang terjadi kembali kepada Allah.

Tabel 9. Semiotika Roland Barthes

\begin{tabular}{|c|c|c|}
\hline \multirow[t]{2}{*}{ Denotasi } & Signifier & Signified \\
\hline & $\begin{array}{l}\text { Pada menit 00:01:17, tampak pada gambar } 8 \text {, } \\
\text { seorang anak kecil berbaju kemeja putih serta } \\
\text { memakai ropi merah sedang berada di sebuah } \\
\text { bangunan, wajahnya cemberut dan mulutnya } \\
\text { membungkam, serta matanya menatap kedepan. } \\
\text { Dibagian bawah pada gambar tersebut terdapat } \\
\text { tulisan "Asyhadu anna Muhammadar Rasülulläh" } \\
\text { dengan huruf Arab berwarna putih. Tepat di } \\
\text { bawah huruf Arab tersebut tampak tulisan "aku } \\
\text { bersaksi bahwa Muhammad adalah Rasul Allah". }\end{array}$ & $\begin{array}{l}\text { Anak laki-laki } \\
\text { kemeja }\end{array}$ \\
\hline Konotasi & Signifier & Signifiec \\
\hline
\end{tabular}




\begin{tabular}{|l|l|l|}
\hline $\begin{array}{l}\text { Seorang anak kecil berseragam sekolah, terlihat kecewa dan sedih setelah uang jajan } \\
\text { yang diberikan ibunya di ambil paksa oleh Bremoro sesaat setelah sampai di sekolah. } \\
\text { Namun meski uang jajannya telah di ambil, ia tetap berusaha sabar dan menahan } \\
\text { emosinya. }\end{array}$ & $\begin{array}{l}\text { Pesal dengan } \\
\text { sifat sabar. }\end{array}$ \\
$\begin{array}{l}\text { Kalimat Asyhadu anna Muhammadar Rasūlullāh merupakan kalimat yang meyakini } \\
\text { bahwa Muhammad adalah utusan Allah, kehadiran Muhammad dimuka bumi adalah } \\
\text { untuk mengubah akhlak manusia dan menjadi suri tauladan bagi ummatnya. Salah } \\
\text { satu sifat baginda Rasul adalah kesabaran. Rasul selalu sabar dalam menghadapi } \\
\text { musuh-musuhnya yang menentang ajarannya. Dan pada bagian tersebut dijelaskan } \\
\text { bentuk kesabaran dalam sebuah visualisasi. }\end{array}$ & \\
\hline Tanda konotasi sabar dalam pergaulan.
\end{tabular}

Pada level denotasi menjadi signifier adalah seluruh tanda nonverbal dan tanda verbal yang terlihat pada tabel 9. Tampak pada gambar saat seorang anak laki-laki yang memakai baju kemeja putih dengan rompi hitam, melihat kedepan, dengan alis yang naik dan mulut yang cemberut. Sementara dibagian bawah gambar terdapat tulisan Asybadu anna Muhammadar Rasülulläh berwarna putih disertai dengan tulisan aku bersaksi bahwa Muhammad adalah Rasul Allah.

Signifier dalam level konotasi di sini adalah makna lain yang terkandung dalam tanda verbal dan tanda nonverbal yang dijelaskan pada level denotasi. Tanda non-verbal dari gambar 8, sebagaimana yang dipaparkan diatas pada level denotasi, bahwa seorang anak laki-laki yang telah berada di sekolah, namun uangnya di ambil paksa oleh Bremoro, tetapi ia tampak diam dengan mata yang berkaca-kaca ia menatap kedepan serta mulut yang membungkam. Adegan yang dilakukan oleh laki-laki tersebut menjadi tolak ukur untuk menentukan pesan yang disampaikan. Bila dilihat dari mitos yang merupakan bagian dari analisis Roland Barthes, maka adegan yang menutup mulut dengan wajah yang hanya diam, adalah bentuk kesabaran yang diperlihatkan seorang anak kecil, saat ia di ganggu ataupun disakiti oleh orang lain. Sedangkan sabar adalah upaya menahan emosi dari orang disekitar saat mendapatkan gangguan ataupun perbuatan buruk lainnya.

Pada tanda verbal dalam durasi menit ke-01 detik ke-17, terdapat tanda verbal kalimat Asyhadu anna Muhammadar Rasülulläh yang merupakan bagian dari kalimat adzan yang menjadi audio dalam tayangan tersebut. Keberadaan nama baginda Rasul SAW dalam kalimat adzan tersebut bukanlah tanpa alasan, banyak hal yang akan didapatkan bila mampu memaknai keberadaan Muhammad Rasulullah dalam kalimat Asyhadu anna Muhammadar Rasülulläh. ${ }^{10}$ Banyak sifat-sifat mulia yang harus dicontoh dari kepribadian Muhammad, sikapnya yang penyabar menjadi sanjungan bagi setiap pengikutnya.

10 Arham Armuza, Rahasia Dabsyatnya Adzan: Hayya Alal Falah (Yogyakarta: Kaukaba Dipantara, 2010), 94. 
Tabel 10. Semiotika Roland Barthes

\begin{tabular}{|c|c|c|c|c|}
\hline \multirow[t]{2}{*}{ Denotasi } & Signifier & Signified & & \\
\hline & $\begin{array}{l}\text { Pada menit 00:01:26, tampak pada } \\
\text { gambar 9, seorang anak kecil berbaju } \\
\text { kemeja putih serta rompi merah sedang } \\
\text { duduk dimeja, wajahnya melihat ke } \\
\text { kanan dan mulutnya cemberut. } \\
\text { Didepannya terlihat botol air minum } \\
\text { dan kotak nasi. Dibagian bawah pada } \\
\text { gambar tersebut tidak terdapat tulisan } \\
\text { apapun. }\end{array}$ & $\begin{array}{l}\text { Anak laki-laki kecil berbaju kemeja putih dan } \\
\text { menggunakan rompi merah adalah Bramantyo, ia } \\
\text { melihat kekanan karena ia baru saja disenggol } \\
\text { tangannya ketika hendak menyuap nasi. Kotak } \\
\text { yang berada didepannya adalah makanan yang } \\
\text { diberikan oleh ibunya saat akan berangkat } \\
\text { kesekolah. Akibat disenggol oleh Bremoro } \\
\text { tersebut nasinya tumpah diatas meja. Bramantyo } \\
\text { hanya melihat Bremoro tanpa melakukan } \\
\text { perlawanan. }\end{array}$ & & \\
\hline \multirow[t]{2}{*}{ Konotasi } & \multicolumn{2}{|r|}{ Signifier } & \multicolumn{2}{|c|}{ Signified } \\
\hline & \multicolumn{2}{|c|}{$\begin{array}{l}\text { pesan yang ingin disampaikan adalah pesan sabar dalam menghadapi permasalahan. } \\
\text { Meskipun nasi yang akan dimakan telah tumpah namun Bramantyo tetap sabar dan tidak } \\
\text { melakukan } \\
\text { perlawanan. }\end{array}$} & $\begin{array}{l}\text { Pesan } \\
\text { dengan } \\
\text { sabar. }\end{array}$ & $\begin{array}{r}\text { moral } \\
\text { sifat }\end{array}$ \\
\hline
\end{tabular}

Pada level denotasi menjadi signifier adalah seluruh tanda nonverbal yang terlihat pada tabel 10 Tampak pada gambar saat seorang anak laki-laki yang memakai baju kemeja putih dan memakai rompi merah, sedang duduk disebuah di meja, didepan anak tersebut terlihat botol air minum dan kotak nasi. Anak kecil tersebut melihat kekanan dengan wajah yang cemberut, dengan latarnya adalah sebuah bangunan yang juga ramai anak kecil.

Signifier dalam level konotasi di sini adalah makna lain yang terkandung dalam tanda nonverbal yang dijelaskan pada level denotasi. Tanda non-verbal dari gambar 9, sebagai mana yang dipaparkan di atas pada level denotasi bahwa seorang laki-laki memakai baju sekolah dan rompi merah sedang duduk dan latar dari anak tersebut adalah keramaian anak yang berbaju putih dan rompi dibelakangnya. Wajah laki-laki kecil ini terlihat cemberut dengan menatap kearah kanan. Bila dilihat dari mitos yang merupakan bagian dari analisis Roland Barthes, maka adegan tersebut memperlihatkan kondisi dilingkungan sekolah terdapat seorang anak laki-laki yang lugu dan kecewa, namun ia berusaha untuk tidak melakukan perlawanan atas gangguan yang ia terima. Seseorang yang diam dan tidak melakukan perlawanan atas perlakuan buruk dari orang-orang disekitarnya adalah bentuk sikap sabar dalam menjalani pergaulan.

Hasil wawancara:

"Kalo bramantyo itu dibikin sebagai anak yang sholeh dan bukan anak yang suka dengan kekerasan. Soalnyakan dia diajarin oleh orang tuanya bahwa sekeras apapun orang kepada kita, ya kita harus memaafkan. karena kalo secara Islam itu kan, jika ada orang yang menampar kita, jangan kita tampar balik tapi kita berdoa kepada Allah bahwa kita sedang mendapatkan cobaan, semoga diberikan kekuatan sebab toh nantinya semua akan berjalan seperti rencana Allah, jadi yang ingin kita bangun disitu adalah si Bramantyo ini anak yang tidak pendendam dan 
tidak suka membalas, meskipun didalam tayangan terlihat kesel karena dilihat dari emosi seorang anak kecil, dia belum paham kenapa harus menahan emosi, dia belum paham mengapa harus menahan dendam, tapi dia masih menghormati orang tuanya karena pesan orang tuanya untuk tidak membalas saat disakiti, makaanya di tidak membalas tapi hanya meredam emosi. emosinya masih terlihat karena ia masih kecil". ${ }^{11}$

\section{Pemaaf}

Keindahan dalam diri Rasulullah salah satunya adalah sikap pemaaf. Pemaaf adalah sikap mulia yang dilakukan seseorang saat ia mendapatkan perlakuan buruk dari orang lain, lalu ia memaafkannya. Memaafkan adalah bentuk kebajikan yang dilakukan oleh seorang yang beriman, sikap saling memaafkan adalah ajaran islam dalam upaya mempererat tali persaudaraan. Di dalam tayangan adzan maghrib di RCTI versi 2014/2015 terdapat sifat pemaaf. Deskripsi data beramal shaleh meliputi tanda yang ditampilkan dalam tabel-tabel berikut:

\section{Tabel 11. Semiotika Roland Barthes}

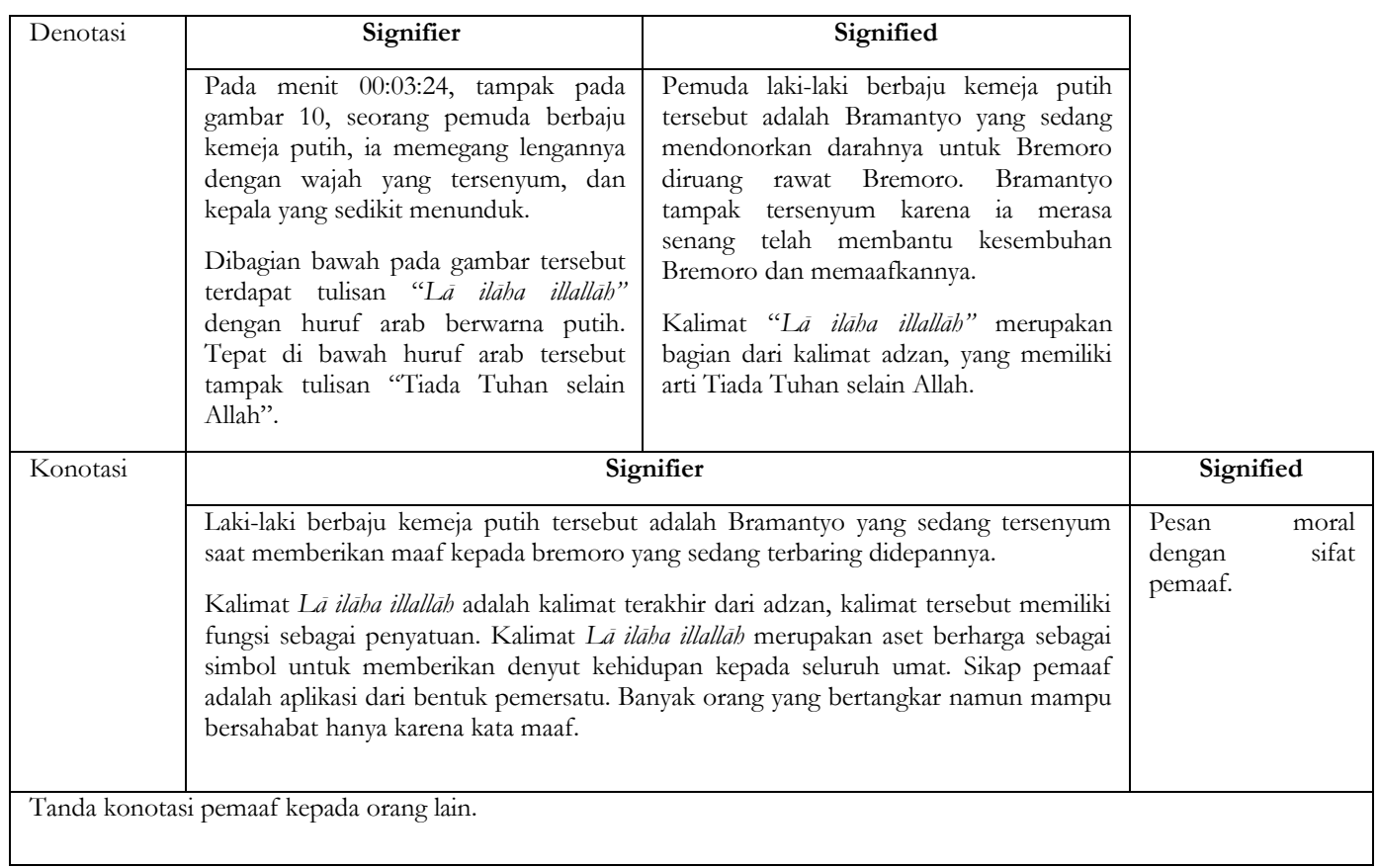

Pada level denotasi menjadi signifier adalah seluruh tanda nonverbal dan tanda verbal yang terlihat pada tabel 11. Tampak pada gambar seorang pemuda memakai baju kemeja putih sedang memegang lengannya, wajahnya tersenyum serta kepala yang sedikit tertunduk. Sementara di bagian bawah gambar terdapat tulisan Là ilāha illallāh berwarna

11 Wawancara dengan Gandes Krisantyo, Kreatif Produksi Tayangan Adzan RCTI, 17 September 2105. 
putih beserta dengan tulisan tiada tuhan selain Allah.

Signifier dalam level konotasi di sini adalah makna lain yang terkandung dalam tanda verbal dan tanda non-verbal yang dijelaskan pada level denotasi. Tanda non-verbal dari gambar 10 adalah sebagaimana yang dipaparkan pada level denotasi diatas bahwa seorang laki-laki yang sedang duduk sambil memegang lengannya dan tersenyum kedepan, konotasi dari adegan tersebut adalah memperlihatkan seorang pemuda berbaju putih yang bernama Bramantyo sedang tersenyum kearah Bremoro yang sedang sakit. Bila dilihat dari mitos yang merupakan bagian dari analisis Roland Barthes, maka orang yang tersenyum sambil menundukkan kepalanya adalah bentuk setuju terhadap ajakan kedamaian antar sesama dan meninggalkan segala bentuk permusuhan atau dalam arti memaafkan.

Pada tanda verbal dalam durasi menit ke-03 detik ke-24, terdapat tanda verbal kalimat Là ilāha illallāh yang merupakan bagian akhir dari kalimat adzan yang menjadi audio dalam tayangan tersebut. Kalimat ini selalu digunakan dan dianjurkan oleh Rasul agar mendiktekan kalimat Là ilāha illallāh kepada orang yang dalam keadaan menjelang ajal. Dalam kehidupan bersosial kalimat ini adalah kalimat yang berfungsi sebagai pemersatu, dengan kalimat ini mampu menembus tembok yang berkotak-kotak. Sehingga keistimewaan kalimat ini adalah kentalnya persaudaraan yang berlandasan Là ilāha illallāh.

Hasil wawancara:

"Diakan sudah di ajarkan, bahwa sejelek apapun orang berbuat kepada kita, maka jangan sampai kita berbuat jelek kepada orang tersebut. nah ini adalah titik balik dari Bramantyo dan titik balik dari Bremoro, sekeras kerasnya dia kepada Bramantyo, tatapi tetap dia adalah manusia juaga dan tetap temen sekolahnya dulu makanya Bramantyo itu dengan iklas memberikan donor darahnya meskipun ia sudah kasar. karena dia sudah dididik oleh orang tuanya tidak boleh kasar, makanya ia tidak melihat, ouu.. ini sudah membully ngapain dibantuin, tidak seperti itu. makanya kepribadian Bramantyo yang tidak pendendam dan tidak membalas itu kelihatan disini. bahwa si Bremoro itu suka membully tapi sekarang ia jatuh sakit, si Bramantyo bukan mengata-ngatain, bukan menjelek-jelekkan, tapi malah membantu karenakan Nabi Muhammad juga begitu, pada saat ada pengemis yang meludahi dia, dia tidak marah. tapi pada saat si pengemis Quraisy itu sakit, Nabi Muhammad yang pertama datang menjenguk". 12

\section{Penutup}

\section{Kesimpulan}

Setelah melakukan penelitian terkait pesan moral dalam tayangan adzan maghrib di RCTI versi tahun 2014-2015 dengan tema "Bertaubat", maka disimpulkan bahwa:

12 Wawancara dengan Gandes Krisantyo, Kreatif Produksi Tayangan Adzan RCTI, 17 September 2105. 
100 |Jurnal Dakwah dan Komunikasi, Vol. , No. , 2019

1. Dalam tayangan adzan maghrib di RCTI versi tahun 2014-2015, menampilkan pesan moral dalam adegan mencium tangan kanan orang yang lebih tua, mengucapkan salam saat bertemu orang lain menunjukkan sikap tawadhu' dalam bentuk menghormati orang tua dan mengucapkan kalimat salam kepada orang lain. Adegan seorang pemuda yang sukses, namun masih selalu bertegur sapa kepada pegawainya menunjukkan sikap lemah lembut dalam bentuk tersenyum kepada bawahan dan tidak bersikap emosional. Adegan pemuda yang telah sukses, namun masih manyuapkan makanan kepada ibunya yang sedang sakit merupakan sikap kasih sayang dalam bentuk merawat dan menyuapkan makanan kepada seorang ibu. Adegan pemuda yang bersedia untuk membantu laki-laki tua yang merupakan bapak dari Bremoro menunjukkan sikap beramal shaleh dalam bentuk kesediaan untuk mendonorkan darahnya kepada orang lain. Adegan tidak membalas atau melakukan perlawanan saat Bramantyo di ganggu dan disakiti oleh Bremoro merupakan sikap sabar dalam bentuk menahan amarah serta berupaya untuk pasrah. Adegan yang memperlihatkan Bramantyo tersenyum dan menundukkan kepalanya ketika Bremoro meminta maaf atas kesalahannya merupakan sikap pemaaf dalam bentuk menunduk sambil tersenyum tipis sebagai tanda perdamaian.

2. Warna putih dari tulisan Arab yang merupakan kalimat adzan dan artinya, tampil di bagian bawah pada tayangan tersebut adalah menggambarkan kesucian atas kalimat adzan yang dikumandangkan pada tayangan tersebut.

\section{Daftar Pustaka}

\section{Buku-buku}

Armuza, Arham, Rahasia Dabsyatnya Adzan: Hayya Alal Falah, Yogyakarta: Kaukaba Dipantara, 2010.

Hajjaj, Muh. Fauqi, Tasawuf Islam \& Akhlak, Terj. Kamran As'at Irsyady \& Fakhri Ghazali, Jakarta: Amzah, 2011.

Ibrahim, Idi Subandi, Bercinta Dengan Televisi, Bandung: Remadja Rosdakarya, 1997. Khaled, Amr, Buku Pintar Akhlak, terj. Fauzi Faisal Bahreisy, Jakarta: Zaman, 2010.

Kuswadi, Wawan, Komunikasi Massa: Sebuah Ananlisis Media Televisi, Jakarta: Rineka Cipta, 1996.

Raco, J.R., Metode Penelitian Kualitatif, Jakarta: Grasindo, 2010.

Rakhmat, Jalaluddin, Metode Penelitian Komunikasi, Bandung: Remaja Rosdakarya. Sobur, Alex, Semiotika Komunikasi, Bandung: Remaja Rosdakarya, 2006.

\section{Website}

Rajawali Citra Televisi Indonesia, Profile Perusahaan, dalam http://www.rcti.tv/profile/ view $/ 1 /$ Profile $\% 20$ Perusahaan. 